\title{
De novo Cortical Cell Division Triggered by the Phytopathogen Rhodococcus fascians in Tobacco
}

\author{
Carmem-Lara de O. Manes, ${ }^{1}$ Marc Van Montagu, ${ }^{1}$ Els Prinsen, ${ }^{2}$ Koen Goethals, ${ }^{1}$ and \\ Marcelle Holsters ${ }^{1}$ \\ ${ }^{1}$ Vakgroep Moleculaire Genetica \& Departement Plantengenetica, Vlaams Interuniversitair Instituut voor \\ Biotechnologie (VIB), Universiteit Gent, B-9000 Gent, Belgium; ${ }^{2}$ Departement Biologie, Universitaire \\ Instelling Antwerpen, B-2610 Antwerpen, Belgium \\ Accepted 18 October 2000.
}

\begin{abstract}
Plant growth, development, and morphology can be affected by several environmental stimuli and by specific interactions with phytopathogens. In many cases, plants respond to pathogenic stimuli by adapting their hormone levels. Here, the interaction between the phytopathogen Rhodococcus fascians and one of its host plants, tobacco, was analyzed phenotypically and molecularly. To elucidate the basis of the cell division modulation and shoot primordia initiation caused by $R$. fascians, tobacco plants were infected at leaf axils and shoot apices. Adventitious meristems that gave rise to multiple-shoot primordia (leafy galls) were formed. The use of a transgenic line carrying the mitotic $C y c B 1$ promoter fused to the reporter gene coding for $\beta$-glucuronidase from Escherichia coli (uidA), revealed that stem cortical cells were stimulated to divide in an initial phase of the leafy gall ontogenesis. Local cytokinin and auxin levels throughout the infection process as well as modulation of expression of the cell cycle regulator gene Nicta;CycD3;2 are discussed.
\end{abstract}

Additional keywords: cyclinD3; epiphylly; phytohormones.

The phytopathogenic gram-positive bacterium Rhodococcus fascians infects a wide range of monocotyledonous and dicotyledonous plants causing several types of malformations. A $200-\mathrm{kb}$ linear plasmid is responsible for pathogenicity and contains virulence genes, one of which codes for an isopentenyl transferase (IPT) homolog that is putatively involved in cytokinin biosynthesis (Crespi et al. 1992).

The effects caused by $R$. fascians vary from a fasciated phenotype to the initiation of multiple-shoot primordia accompanied by the suppression of shoot outgrowth, resulting in a leafy gall. The phenotypes depend on the host and the age of the plant as well as on the inoculation method and site of infection. Nicotiana tabacum (L.) and Arabidopsis thaliana (L.) Heynh. were used as model plants to investigate morphological aspects of $R$. fascians infection. When tobacco plants are decapitated and infected, multiple lateral shoots are formed at

Corresponding author: M. Holsters; E-mail: mahol@gengenp.rug.ac.be Fax: +32 92645349 the site of the wounding that give rise to a leafy gall (Vereecke et al. 2000). Morphological changes observed after vacuum infiltration of $A$. thaliana include increased number of flowers, early flowering, outgrowth of axillary meristems, overall stunted phenotype as well as abnormal flower formation, and altered leaf shape (T. M. Ritsema, C.-L. de O. Manes, K. Goethals, and M. Holsters, unpublished).

Plant morphogenesis relies essentially on cell division and expansion because plant cells do not migrate. In mature plants, cell division is restricted to meristematic regions. Shoot and root meristems show specific patterns of cell division that are controlled genetically (Meyerowitz 1997). Nevertheless, most plant cells are capable of changing their fate in response to appropriate stimuli. Cell division patterns and rates are affected by different factors such as temperature, nutrient and water availability, and pathogen attack (Ben-HajSalah and Tardieu 1995; Dudley et al. 1987; Gastal and Nelson 1994; Sacks et al. 1997).

Recently, many efforts were made to obtain a clear picture of the eukaryotic cell cycle machinery and its regulation. Cellcycle progression can be arrested at different phases and reactivated through the induction of regulatory proteins. The key components are the cyclins and the cyclin-dependent kinases (CDKs). Cell division is regulated by the activation of CDKs through the binding of cyclins. In plants, several genes that encode cell-cycle regulators have been isolated, and their expression pattern and/or associated protein activity investigated (Mironov et al. 1999). Several studies demonstrated that nutrients, cytokinins, and auxins up regulate D-type cyclins and Atype CDK transcripts (Carle et al. 1998; De Veylder et al. 1999; Fuerst et al. 1996; Tréhin et al. 1998). Additionally, endogenous cytokinin, in particular zeatin, is required for cellcycle progression in $\mathrm{BY}_{2}$-cultured cells (Laureys et al. 1998; Redig et al. 1996). Recently, Riou-Khamlichi et al. (1999) observed that the $C y c D 3$ transcript is up regulated by zeatin and its overexpression triggers the formation of cytokininindependent calluses. In addition to a role in cell division, cytokinins interfere in cell expansion, releasing axillary bud dormancy and delaying leaf senescence. Altered endogenous cytokinin levels and their relation to morphological changes have been investigated extensively by the genetic engineering of different plant species (Li et al. 1992; McKenzie et al. 
1994; Medford et al. 1989; Roeckel et al. 1998; Schmülling et al. 1993). The overall morphological changes caused by $R$. fascians on its hosts and the presence of an IPT gene on the linear plasmid suggest that cytokinins might play an important role in symptom development. Although several virulence genes of $R$. fascians have been identified to date (Crespi et al. 1994), the signaling for pathogenicity is still unknown. Here, we study leafy gall ontogenesis, starting at the initiation of cell division in tobacco stem cortical cells triggered by $R$. fascians infection. The endogenous hormone levels through- out the infection process as well as the modulation of cellcycle gene expression are evaluated and discussed.

\section{RESULTS}

\section{Spot inoculation assay.}

Different methods were used to infect host plants with $R$. fascians such as decapitation site infection, vacuum infiltration, and watering (Vereecke et al. 2000). The symptoms displayed by the infected plants were not homogeneous and, except
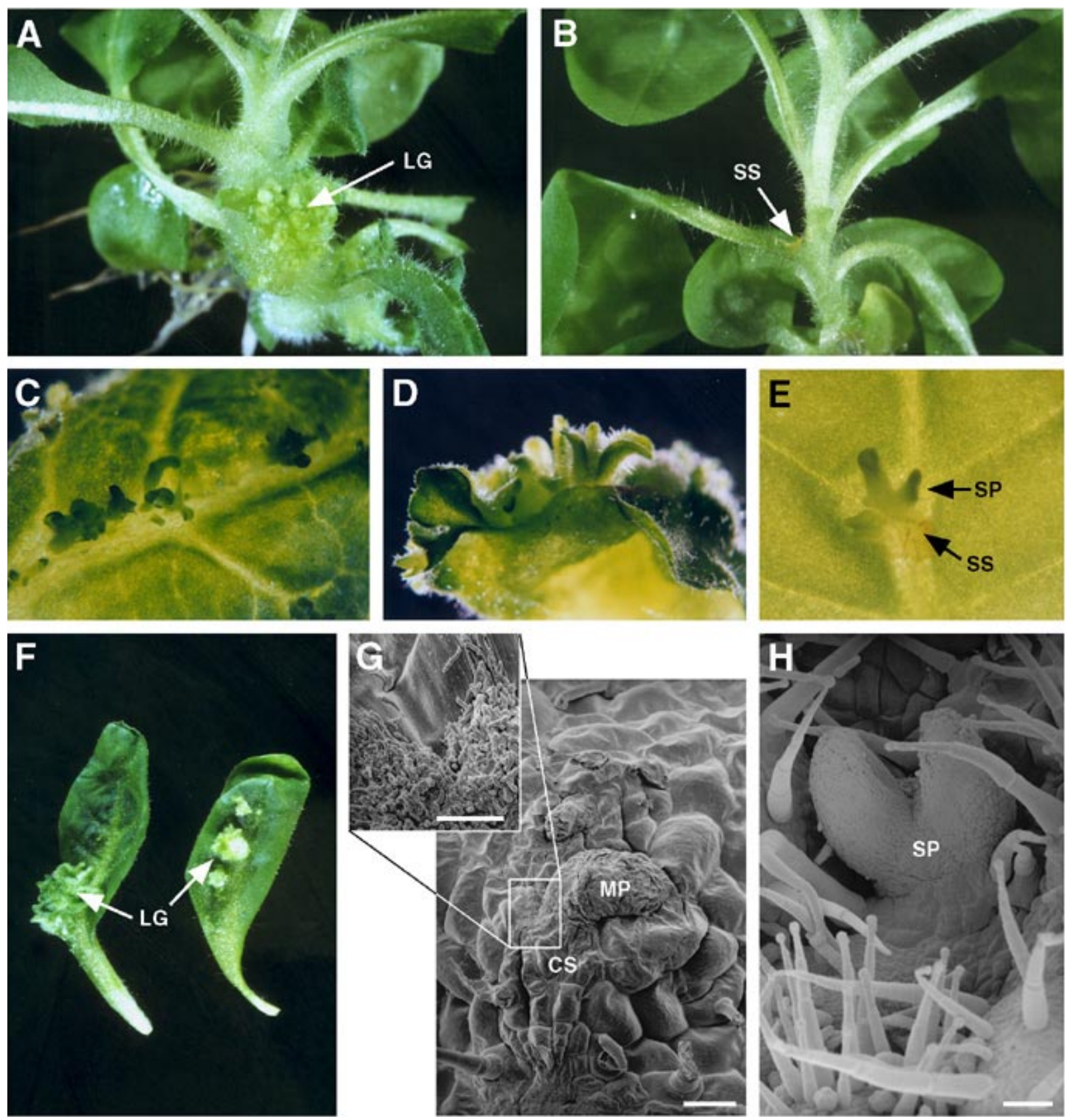

Fig. 1. Tobacco phenotypes in response to Rhodococcus fascians spot inoculations. A, Leafy gall derived from an infected leaf axil. B, Control plant infected with the nonvirulent strain D188-5 of $R$. fascians. C and D, Epiphyllous shoots on the leaf blade and leaf margin. E, Shoot primordium arising from locally spotted site. F, Leafy gall originated from (E). G, Scanning electron micrograph of an infected leaf midrib showing epidermal cell swelling and meristem primordium. Detail of colonization site of $R$. fascians surrounding meristem primordium. $\mathbf{H}$, Scanning electron micrograph of an adventitious shoot primordium originated from a leaf blade spot infection. $\mathrm{CS}=$ colonization site; $\mathrm{LG}=$ leafy gall; $\mathrm{MP}=$ meristem primordium; $\mathrm{SP}=$ shoot primordium; SS = spot site. Bars $=100 \mu \mathrm{m}(\mathbf{G}$ and $\mathbf{H})$ and $10 \mu \mathrm{m}$ (inset). 

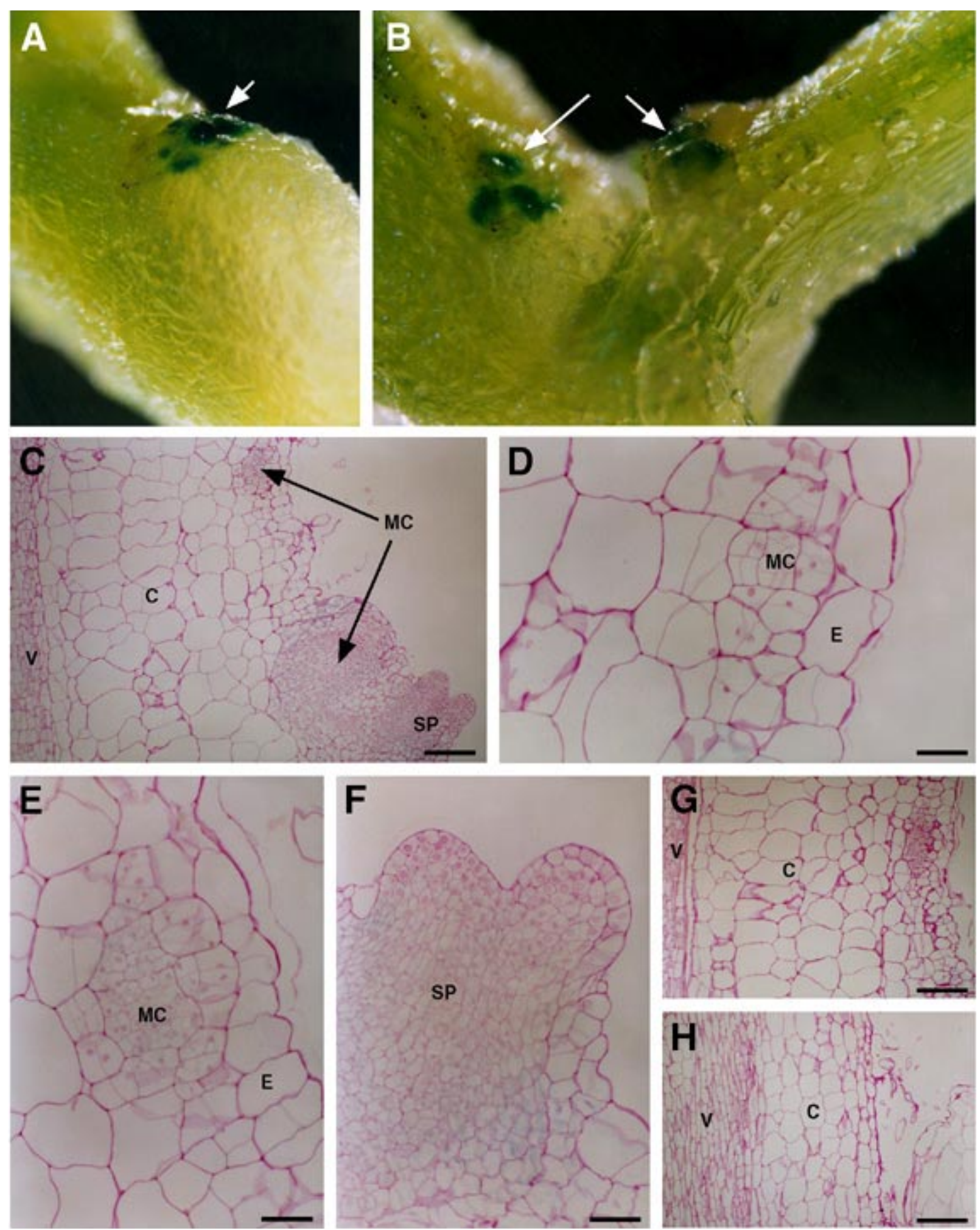

Fig. 2. CycB1;1 promoter activity and microscopic analysis of a tobacco transgenic line spot-inoculated with Rhodococcus fascians. A and B, GUS expression indicates dividing cells (arrows) after inoculation of leaf axils. C, Longitudinal sections of an inoculated axil show mitotic centers and a shoot primordium originating from the outer cortical cells of the stem. D, Details from cortical cell division initiation. $\mathbf{E}$ and $\mathbf{F}$, Shoot primordium formation. G, Overview of cortical cells from a spot-inoculated plant. $\mathbf{H}$, Noninfected cortical cells. $\mathrm{C}=$ cortex; $\mathrm{E}=$ epidermis; $\mathrm{MC}=$ mitotic center; $\mathrm{SP}=$ shoot primordium; V = vascular tissue. Bars $=200 \mu \mathrm{m}(\mathbf{C}, \mathbf{G}$, and $\mathbf{H})$ and $50 \mu \mathrm{m}(\mathbf{D}$ to $\mathbf{F})$. 
for decapitated plants, these methods were not adequate to obtain localized responses. To avoid the above-mentioned drawbacks, a localized, nondamaging infection method was developed. Leaf axils of tobacco plants were inoculated with a droplet of a log-phase culture of $R$. fascians. After 1 week, these areas invariably formed meristem initials that developed into a leafy gall 4 weeks later (Fig. 1A and B). No positional preference from which axil (younger-older) responded to spot inoculation was observed. Spot inoculation also was performed on the leaf blade and the shoot apex. Invariably, when the shoot apex was infected, developing leaves displayed epiphyllous shoots along the vasculature and sometimes at the margins (Fig. 1C and D). For the leaf blade spot inoculation, the frequency of responses varied according to the developmental stage and spotting site. Young leaves responded better, and infection at the leaf pedicel and midrib produced more reproducible responses, leading to activation of adventitious meristems (Fig. 1E) and leafy gall formation (Fig. 1F).

$R$. fascians colonizes the surface and internal spaces of the leaf tissue, but colonization is not always related to symptom development because virulent and nonvirulent strains have comparable surface-colonization capacities (K. Cornelis, T., Ritsema, J. Nijsse, M. Holsters, K. Goethals, and M. El Jaziri, unpublished). Scanning electron microscopy was performed on the infected tissues to investigate whether newly formed structures contained bacteria. Invariably, in the vicinity of leaf bladeborne shoots, scattered bacterial clusters were found but occurred rarely on the newly formed shoots themselves (Fig. $1 \mathrm{G}$ and $\mathrm{H}$ ). The same observation was made when petiole and stem-derived adventitious shoots were analyzed. Therefore, we can suggest that shoot primordia formation is restricted to colonization sites.

\section{From cortical cell division to leafy gall ontogenesis.}

Morphological analysis of tobacco plants infected by $R$. fascians suggests that cell division and expansion are affected. To observe the first events induced by $R$. fascians, a transgenic line of tobacco carrying the mitotic $C y c B 1 ; 1$ promoter-gus fusion was used (Ferreira et al. 1994). The $C y c B 1 ; 1$ promoter is active at the G2-to-M transition and during mitosis (Shaul et al. 1996). Segments of stems comprising infected areas were harvested 1, $3,5,7$, and 14 days after spot inoculation at leaf axils. The first visible symptom was a thickening of the stem 4 days after infection. Actively dividing cells, as shown by GUS staining, appeared 4 to 7 days after infection (Fig. 2A and B). Serial, longitudinal thin sections were stained and scored for the presence of mitotic figures and early cell-division events. At day 1 and 3 after infection, no major morphological changes were found in infected tissues compared with noninfected tissues or tissues infected with an nonvirulent strain of $R$. fascians. Seven days postinoculation, mitotic figures were observed in the outer cortical cells of stems infected with wild-type bacteria (Fig. 2C to E). In this case, cell-division events always correlated with a faint GUS staining in the ultrathin sections. The dividing cells were reoriented to form a shoot meristem that developed a leaf primordium and later into a shoot with inhibited outgrowth (Fig. $2 \mathrm{~F})$. At the infection site, inner and outer cortical cells of the stem were enlarged (Fig. 2G and H).

Cytokinin and auxin contents of infected areas.

Cell division and differentiation are controlled by hormones. To correlate activation of cortical cell division with altered hormone levels at the site of infection, plants were spot inoculated with virulent and nonvirulent strains (control plants) of $R$. fascians at the leaf axils. One, 2, and 3 weeks postinoculation, stem segments comprising the infected axils were harvested for local determination of cytokinins and indole-3-acetic acid (IAA) levels by immunoaffinity chromatography with a broad-spectrum antibody (Prinsen et al. 1995a; Prinsen et al. 1998). The data obtained indicated that the measurement levels of cytokinin bases (zeatin, dihydrozeatin, and isopententenyl adenine) or their derivatives (ribotides, glucosides, and phosphates) were too low to be significant (data not shown). In contrast, during the first 2 weeks of the infection process, IAA levels were higher in tissues inoculated with the virulent strain of $R$. fascians than in control tissues: 89.4 and 224.0 pmol of IAA per $g$ (fresh weight) was obtained compared with 56.4 and 146.0 pmol of IAA per $g$ in control tissues 1 and 2 weeks postinoculation, respectively.

\section{CycD3;2 transcript levels are enhanced by $R$. fascians infection and by cytokinins.}

D-type cyclin genes were isolated from tobacco and their expression patterns during cell cycle were investigated by Sorrell et al. (1999), who showed that the Nicta; $C y c D 3 ; 2$ transcripts were induced rapidly as stationary cells reentered the cell cycle. To evaluate the effect of $R$. fascians inoculation on Nicta; $C y c D 3 ; 2$ expression, a RNA gel blot analysis was performed with RNA from spotted axils with Nicta; $C y c D 3 ; 2$ as a hybridization probe. The results showed that 5 days postinfection, the $C y c D 3 ; 2$ transcript levels increased up to fourfold when compared with control material infected with the nonpathogenic strain (Fig. 3A). The tobacco $C y c D 3 ; 2$ also was induced in seedlings treated with $1 \mu \mathrm{M}$ zeatin for $24 \mathrm{~h}$ (Fig. 3B).

\section{DISCUSSION}

We used a nondamaging infection assay to investigate the $R$. fascians-host interaction at responsive tissues such as leaf axils, leaf blade, and shoot apex. The homogenous responses obtained were the activation of axillary and adventitious meristems that developed in a structure defined as leafy gall. The ontogenesis of this particular symptom has not been described previously. We show that the initial step of leafy gall formation is de novo cell division in the outer cortical cells of stems. Dividing cells form a meristem that acquires zonation and develops into a shoot primordium. Interestingly, a parallel can be made with the induction of nitrogen-fixing root nodules in the Rhizobium-legume symbiosis. There, upon stimulation by nod factors, root cortical cells dedifferentiate and start to divide, establishing a nodule primordium (Yang et al. 1994). Signals derived from $R$. fascians induce a mitosis in the outer cortical cells of the stem. Because no evidence for enhanced levels of common cytokinins or cytokinin derivatives during the infection process could be obtained, the hypothesis proposed is that novel types of bacterially produced cytokinin analogs are involved in this process. A previously reported enhancement in IAA levels of infected plants (Vereecke et al. 2000) could be confirmed by a more sensitive technique. However, the origin of the auxin is not clear: it can be correlated with the formation of multiple meristems, which are known sources of auxin production in plants, or with bacterially produced auxins. 
The shoot outgrowth in the leafy gall is inhibited, possibly as a result of an extreme apical dominance exerted by each lateral shoot primordium over its neighbors. When a leafy gall is set free from bacteria by antibiotic treatment and is placed on growth medium, normal shoots develop to form a phenotypically normal plant (Vereecke et al. 2000). These data corroborate Lacey's (1936) statement that the presence of the bacteria is crucial for symptom maintenance. Here, symptom development is correlated with the presence of bacteria by the microspotting assay, and responsive colonization sites develop into a leafy gall structure, whereas the rest of the plant continues to grow normally.

Another feature of the system is the induction of epiphyllous shoots. Few data are available on adventitious meristem activation in planta. Naturally occurring epiphyllous shoots are found in the ornamental plant Kalanchoe daigremontiana and are thought to arise from leaf margin cells that are blocked in the G1 phase. These cells are reactivated to form undifferentiated meristems that further develop into a small shoot (Kerstetter and Hake 1997). Epiphylly has been observed in plants that overexpress members of the $\mathrm{Knl}$ class of plant homeobox genes and in plants overexpressing a cytokinin synthesis gene (ipt) from Agrobacterium tumefaciens (Chuck et al. 1996; Li et al. 1992; Sinha et al. 1993). Recently, Rupp et al. (1999) showed a direct link between cytokinin overproduction in transgenic ip overexpressing Arabidopsis spp. lines and increased mRNA steady-state levels of KNAT1 and STM homeobox genes. Both gene transcripts also are enhanced in the cytokinin overproducing shoot meristem mutant ampl. Together these findings suggest that homeobox gene overexpression and cytokinin overproduction act in the same developmental pathway.

The main advantage of the $R$. fascians-tobacco system relies in the fact that locally infected plant tissues respond to the bacterial stimuli, thus providing homogenous and specific material to investigate aspects of shoot development at the physiological and molecular level.

A

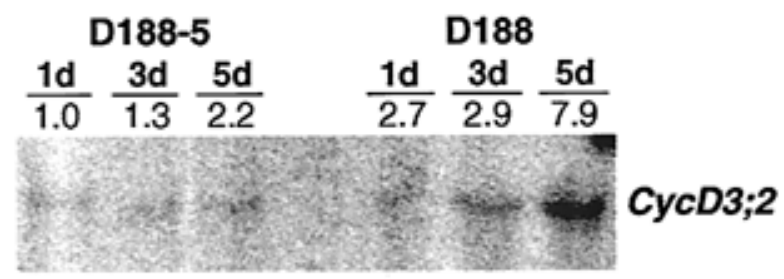

B

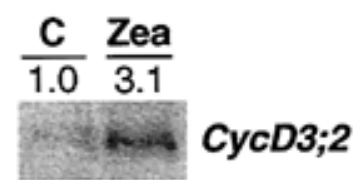

Fig. 3. Nicta; $C y c D 3 ; 2$ RNA induction by Rhodococcus fascians and cytokinin. A, Tobacco spot-infected axils 1, 3, and 5 days postinoculation with $R$. fascians virulent (D188) and nonvirulent (D188-5) strains. B, Tobacco seedlings grown 7 days in liquid Murashige and Skoog (MS) medium and treated $24 \mathrm{~h}$ with $\mathrm{MS}$ alone $(\mathbf{C})$ or supplemented with $1 \mu \mathrm{M}$ zeatin (Zea). Gray density values (1.0-7.9) indicate approximate inducibility.
Currently, cell-cycle markers are used to study the molecular basis of plant responses toward environmental factors such as stress, pathogens, nutrients, light, and hormones. In the field of plant-microbe interactions, these genes have been used to study nodule formation upon Rhizobium sp. infection (Goormachtig et al. 1997; Yang et al. 1994) and the formation of giant cells and syncytia caused by nematodes (De Almeida Engler et al. 1999; Niebel et al. 1996). Cell-cycle markers proved to be a useful tool to analyze the initial stages of the $R$. fascians-tobacco interaction. By assaying the $C y c B 1 ; 1$ promoter activity, we observed the first cell-division events 3 days after infection. The main result was the correlation of the $C y c D 3 ; 2$ transcript inducibility by $R$. fascians stimuli. D-type cyclins are involved in the regulation of the G1-to-S transition. When stimulated to reenter the cell cycle, quiescent cells show enhanced transcript levels of D-type cyclin genes (Soni et al. 1995). For what we believe is the first time in planta, we show the enhancement of $C y c D 3 ; 2$ transcript levels triggered by a phytopathogen. Our data indicate that signals of $R$. fascians are capable of reprogramming cells to reenter the cell cycle in a controlled, patterned way because the final result is the formation of a well-defined structure, the leafy gall.

\section{MATERIALS AND METHODS}

\section{Plant material and growth conditions.}

N. tabacum (L.) cv. (W38) and Petit Havana (SR1), including the transgenic pCycB1;1-gus line (Ferreira et al. 1994), were grown in vitro on half-strength Murashige and Skoog (MS) (1962) medium under a $16-\mathrm{h}$ photoperiod at $24 \pm 2{ }^{\circ} \mathrm{C}$.

\section{Bacterial strains.}

R. fascians strains D188 (pathogenic) and D188-5 (a plasmid-free, nonpathogenic strain) (Desomer et al. 1988) were grown in solid or liquid YEB medium (Miller 1972) at $28^{\circ} \mathrm{C}$.

\section{Spot infections.}

Bacteria from a late, exponential 2-day-old culture were centrifuged, washed, and resuspended in $0.2 \mathrm{M}$ phosphate buffer (pH 5.7) containing 0.05\% Na-citrate, $0.025 \% \mathrm{MgSO}_{4}$, and $0.001 \%$ thiamine. Aliquots $(0.5$ to $2 \mu \mathrm{l})$ of the bacterial suspension were applied with a glass micropipette that was eventually sustained by a micromanipulator on the target areas.

\section{Histochemical GUS assays.}

The histochemical GUS assays were carried out according to Jefferson (1987), with some modifications described by Hemerly et al. (1993). Sections were observed and photographed under a Stemi SV11 stereomicroscope (Zeiss, Jena, Germany).

\section{Microscopic analysis.}

Plastic embedding by Technovit 7100 resin (Kulzer HistoTechnik, Wehrheim, Germany) and sectioning were performed according to the manufacturer's protocol. Serial sections (5 $\mu \mathrm{m})$ were stained with ruthenium red (Sigma, St. Louis, MO, U.S.A.) $0.05 \% \mathrm{wt} / \mathrm{vol}$ water solution and mounted with Depex mounting medium (Gurr, Poole, England). Sections were photographed under a Diaplan light microscope (Leitz, Heerbrugg, Switzerland). Scanning electron microscopy was performed according to Vereecke et al. (2000). 


\section{Nicta;CycD3;2 probe synthesis.}

First-strand cDNA from total RNA extracted from N. tabacum cv. (W38) stems was synthesized with the SuperScript preamplification system kit (GIBCO-BRL, Gaithersburg, MD, U.S.A.). One-tenth of the reaction mixture was used for the PCR amplification of a fragment from the tobacco $C y c D 3 ; 2$ gene (Sorrell et al. 1999) in $50 \mu \mathrm{l}$ of PCR mixture containing $1.5 \mathrm{mM} \mathrm{MgCl} 2,1 \times$ PCR buffer II (Perkin Elmer, Norwalk, CT, U.S.A.), all four deoxynucleotide triphosphates $(0.2 \mathrm{mM}$ each), $0.2 \mu \mathrm{M}$ of each primer ( $\mathrm{F}$ and $\mathrm{R}$ ), and five units of AmpliTaq (Perkin Elmer). The oligonucleotides used as primers were designed according to sequence information (GenBank accession no. AJ011894) by the SeqLab-prime computer program, version 10.0 (Genetics Computer Group, Madison, WI, U.S.A.): F, forward (5'-GGAAAATGAATCCAGTGACACC$\left.3^{\prime}\right)$ and $\mathrm{R}$, reverse (5'-CCGACCACGAATCATTACAG-3'). Thirty-five cycles at $95^{\circ} \mathrm{C}$ for $30 \mathrm{~s}, 55^{\circ} \mathrm{C}$ for $45 \mathrm{~s}, 72^{\circ} \mathrm{C}$ for 3 min, and a final extension of 5 min were performed. A fragment of the expected 420-bp size and sequence was purified from an agarose gel with the QIAquick gel extraction kit (Qiagen, Hilden, Germany) and used to prepare radiolabeled DNA probes with the T7 QuickPrime system (Amersham Pharmacia Biotech, Little Chalfont, U.K.).

\section{RNA analyses.}

Total RNA was isolated with the RNeasy plant mini kit (Qiagen), according to the manufacturer's protocol. Twentyfive micrograms of RNA samples per lane were separated on $1.2 \%$ agarose-formaldehyde gel and transferred to Hybond-N filters (Amersham Pharmacia Biotech). RNA blots were stained with methylene blue to confirm equal loading. Filters were hybridized for $16 \mathrm{~h}$ with radiolabeled DNA probes at $65^{\circ} \mathrm{C}$ in hybridization buffer $(100 \mathrm{mM}$ phosphate buffer, $\mathrm{pH}$ $7.2 ; 7 \%$ sodium dodecyl sulfate; $0.5 \mathrm{mM}$ EDTA) with $1 \%$ bovine serum albumin and $20 \mu \mathrm{g}$ of denatured herring sperm per $\mathrm{ml}$ and washed for $15 \mathrm{~min}$ with $0.5 \times$ hybridization buffer once at room temperature and twice at $65^{\circ} \mathrm{C}$. Hybridized filters were exposed in a PhosphorImage cassette (Amersham Pharmacia Biotech) for 10 days.

\section{Hormone analyses.}

Cytokinins and IAA were purified and measured as described previously (Prinsen et al. 1995a; Prinsen et al. 1995b). Cytokinins were extracted overnight from $0.5 \mathrm{~g}$ of frozen tissue in $\mathrm{CHCl}_{3}$-methanol (MeOH)-water-acetic acid (Bieleski 1964) and purified by combining solid-phase extraction and immunoaffinity chromatography with a broad-spectrum anticytokinin antibody. The $20 \mathrm{ng}$ each of stable isotopes ${ }^{2} \mathrm{H}_{5}-\mathrm{Z}$, ${ }^{2} \mathrm{H}_{5}$-[9R]Z, $\quad{ }^{2} \mathrm{H}_{5}$-[9G]Z, $\quad{ }^{2} \mathrm{H}_{5}-[7 \mathrm{G}] \mathrm{Z}, \quad{ }^{2} \mathrm{H}_{5}-(\mathrm{OG}) \mathrm{Z}, \quad{ }^{2} \mathrm{H}_{5^{-}}$ (OG)[9R]Z, ${ }^{2} \mathrm{H}_{5}$-[9R]Z-phosphate, ${ }^{2} \mathrm{H}_{6}$-iP, ${ }^{2} \mathrm{H}_{6}$-[9R]iP and, ${ }^{2} \mathrm{H}_{6}$-[9G]iP (Apex International, Honiton, U.K.) were added as an internal tracer for recovery and analytical purposes. The different cytokinin fractions obtained after purification were analyzed by $(+)$ ES micro LC/LC-MRM-MS/MS (Prinsen et al. 1995a; Prinsen et al. 1998). IAA was extracted overnight from $0.5 \mathrm{~g}$ of frozen tissue in $80 \% \mathrm{MeOH}(9 \mathrm{ml}$ of fresh weight per $\mathrm{g}$ ) and $50 \mathrm{ng}$ of (phenyl- ${ }^{13} \mathrm{C}_{6-}$ )-IAA (Cambridge Isotope Laboratories, Andover, MA, U.S.A.) was initially added as internal tracer for recovery and analytical purposes. After pentafluorobenzyl derivatization of IAA, pentaflurobenzyl-IAA was analyzed by negative-ion chemical ionization
GC-SIR-MS (Epstein and Cohen 1981). Prior to purification, IAA conjugates were converted to free IAA by alkaline hydrolysis (Bialek and Cohen 1989). The data presented correspond to the average of 20 to 30 pooled infected axils in one experiment.

\section{ACKNOWLEDGMENTS}

We thank S. Öden for her skillful technical assistance in the hormone measurements, D. Inzé, D. Vereecke, and R. Barrôco for critical reading of the manuscript, M. De Cock for preparing it, and R. Verbanck and K. Spruyt for artwork. This work was partially financed by the Interuniversity Poles of Attraction Programme (Belgian State, Prime Minister's Office-Federal Office for Scientific, Technical and Cultural Affairs; P4/15). C.-L. de O. Manes is indebted to the Coordenação de Aperfeiçoamento de Pessoal de Nível Superior (CAPES 1645/98-0) for a predoctoral fellowship.

\section{LITERATURE CITED}

Ben-Haj-Salah, H., and Tardieu, F. 1995. Temperature affects expansion rate of maize leaves without change in spatial distribution of cell length. Plant Physiol. 109:861-870.

Bialek, K., and Cohen, J. D. 1989. Quantitation of indoleacetic acid conjugates in bean seeds by direct tissue hydrolysis. Plant Physiol. 90:398-400.

Bieleski, R. L. 1964. The problem of halting enzyme action when extracting plant tissues. Anal. Biochem. 9:431-442.

Carle, S. A., Bates, G. W., and Shannon, T. A. 1998. Hormonal control of gene expression during reactivation of the cell cycle in tobacco mesophyll protoplasts. J. Plant Growth Regul. 17:221-230.

Chuck, G., Lincoln, C., and Hake, S. 1996. KNAT1 induces lobed leaves with ectopic meristems when overexpressed in Arabidopsis. Plant Cell 8:1277-1289.

Crespi, M., Messens, E., Caplan, A. B., Van Montagu, M., and Desomer, J. 1992. Fasciation induction by the phytopathogen Rhodococcus fascians depends upon a linear plasmid encoding a cytokinin synthase gene. EMBO J. 11:795-804.

Crespi, M., Vereecke, D., Temmerman, W., Van Montagu, M., and Desomer, J. 1994. The fas operon of Rhodococcus fascians encodes new genes required for efficient fasciation of host plants. J. Bacteriol. 176:2492-2501.

De Almeida Engler, J., De Vleesschauwer, V., Burssens, S., Celenza, J. L. Jr., Inzé, D., Van Montagu, M., Engler, G., and Gheysen, G. 1999. Molecular markers and cell cycle inhibitors show the importance of cell cycle progression in nematode-induced galls and syncytia. Plant Cell 11:793-807.

De Veylder, L., De Almeida Engler, J., Burssens, S., Manevski, A., Lescure, B., Van Montagu, M., Engler, G., and Inzé, D. 1999. A new D-type cyclin of Arabidopsis thaliana expressed during lateral root primordia formation. Planta 208:453-462.

Desomer, J., Dhaese, P., and Van Montagu, M. 1988. Conjugative transfer of cadmium resistance plasmids in Rhodococcus fascians strains. J. Bacteriol. 170:2401-2405.

Dudley, M. E., Jacobs, T. W., and Long, S. R. 1987. Microscopic studies of cell divisions induced in alfalfa roots by Rhizobium meliloti. Planta 171:289-301.

Epstein, E., and Cohen, J. D. 1981. Microscale preparation of pentafluorobenzyl esters: Electron-capture gas chromatographic detection of indole-3-acetic acid from plants. J. Chromatogr. 209:413-420.

Ferreira, P. C. G., Hemerly, A. S., De Almeida Engler, J., Van Montagu, M., Engler, G., and Inzé, D. 1994. Developmental expression of the Arabidopsis cyclin gene cyclAt. Plant Cell 6:1763-1774.

Fuerst, R. A. U. A., Soni, R., Murray, J. A. H., and Lindsey, K. 1996. Modulation of cyclin transcript levels in cultured cells of Arabidopsis thaliana. Plant Physiol. 112:1023-1033.

Gastal, F., and Nelson, C. J. 1994. Nitrogen use within the growing leaf blade of tall fescue. Plant Physiol. 105:191-197.

Goormachtig, S., Alves-Ferreira, M., Van Montagu, M., Engler, G., and Holsters, M. 1997. Expression of cell cycle genes during Sesbania rostrata stem nodule development. Mol. Plant-Microbe Interact. 
10:316-325.

Hemerly, A. S., Ferreira, P., De Almeida Engler, J., Van Montagu, M., Engler, G., and Inzé, D. 1993. $c d c 2 a$ expression in Arabidopsis is linked with competence for cell division. Plant Cell 5:1711-1723.

Jefferson, R. A. 1987. Assaying chimeric genes in plants: The GUS gene fusion system. Plant Mol. Biol. Rep. 5:387-405.

Kerstetter, R. A., and Hake, S. 1997. Shoot meristem formation in vegetative development. Plant Cell 9:1001-1010.

Lacey, M. S. 1936. Further studies on a bacterium causing fasciation of sweet peas. Ann. Appl. Biol. 23:743-751.

Laureys, F., Dewitte, W., Witters, E., Van Montagu, M., Inzé, D., and Van Onckelen, H. 1998. Zeatin is indispensable for the $\mathrm{G}_{2}-\mathrm{M}$ transition in tobacco BY-2 cells. FEBS Lett. 426:29-32.

Li, Y., Hagen, G., and Guilfoyle, T. J. 1992. Altered morphology in transgenic tobacco plants that overproduce cytokinins in specific tissues and organs. Dev. Biol. 153:386-395.

McKenzie, M. J., Jameson, P. E., and Poulter, R. T. M. 1994. Cloning an ipt gene from Agrobacterium tumefaciens: Characterisation of cytokinins in derivative transgenic plant tissue. Plant Growth Regul. $14: 217-228$.

Medford, J. I., Horgan, R., El-Sawi, Z., and Klee, H. J. 1989. Alterations of endogenous cytokinins in transgenic plants using a chimeric isopentenyl transferase gene. Plant Cell 1:403-413.

Meyerowitz, E. M. 1997. Genetic control of cell division patterns in developing plants. Cell 88:299-308.

Miller, J. H. 1972. Experiments in Molecular Genetics. Cold Spring Harbor Laboratory Press, Cold Spring Harbor, NY, U.S.A.

Mironov, V., De Veylder, L., Van Montagu, M., and Inzé, D. 1999. Cyclin-dependent kinases and cell division in higher plants: The nexus. Plant Cell 11:509-521.

Murashige, T., and Skoog, F. 1962. A revised medium for rapid growth and bio assays with tobacco tissue cultures. Physiol. Plant 15:473497.

Niebel, A., De Almeida Engler, J., Hemerly, A., Ferreira, P., Inzé, D., Van Montagu, M., and Gheysen, G. 1996. Induction of $c d c 2 a$ and cyclAt expression in Arabidopsis during early phases of nematode-induced feeding cell formation. Plant J. 10:1037-1043.

Prinsen, E., Redig, P., Van Dongen, W., Esmans, E. L., and Van Onckelen, H. 1995a. Quantitative analysis of cytokinins by electrospray tandem mass spectrometry. Rapid Commun. Mass Spectrom. 9:948-953.

Prinsen, E., Redig, P., Strnad, M., Galis, I., Van Dongen, W., and Van Onckelen, H. 1995b. Quantifying plant hormones in transformed plants. Pages 245-262 in: Agrobacterium Protocols (Methods in Molecular Biology, Vol. 44). K. M. A. Gartland and M. R. Davey, eds. Humana Press, Totowa, NJ, U.S.A.

Prinsen, E., Van Dongen, W., Esmans, E. L., and Van Onckelen, H. A. 1998. Micro and capillary liquid chromatography tandem mass spectrometry: A new dimension in phytohormone research. J. Chromatogr. A 826:25-37.
Redig, P., Shaul, O., Inzé, D., Van Montagu, M., and Van Onckelen, H. 1996. Levels of endogenous cytokinins, indole-3-acetic acid and abscisic acid during the cell cycle of synchronized tobacco BY-2 cells. FEBS Lett. 391:175-180.

Riou-Khamlichi, C., Huntley, R., Jacqmard, A., and Murray, J. A. H. 1999. Cytokinin activation of Arabidopsis cell division through a Dtype cyclin. Science 283:1541-1544.

Roeckel, P., Oancia, T., and Drevet, J. R. 1998. Phenotypic alterations and component analysis of seed yield in transgenic Brassica napus plants expressing the $t z s$ gene. Physiol. Plant 102:243-249.

Rupp, H.-M., Frank, M., Werner, T., Strnad, M., and Schmülling, T 1999. Increased steady state mRNA levels of the STM and KNATI homeobox genes in cytokinin overproducing Arabidopsis thaliana indicate a role for cytokinins in the shoot apical meristem. Plant J. 18:557-563

Sacks, M. M., Silk, W. K., and Burman, P. 1997. Effect of water stress on cortical cell division rates within the apical meristem of primary roots of maize. Plant Physiol. 114:519-527.

Schmülling, T., Fladung, M., Grossmann, K., and Schell, J. 1993. Hormonal content and sensitivity of transgenic tobacco and potato plants expressing single rol genes of Agrobacterium rhizogenes T-DNA. Plant J. 3:371-382.

Shaul, O., Mironov, V., Burssens, S., Van Montagu, M., and Inzé, D. 1996. Two Arabidopsis cyclin promoters mediate distinctive transcriptional oscillation in synchronized tobacco BY-2 cells. Proc. Natl. Acad. Sci. USA 93:4868-4872.

Sinha,, N. R., Williams, R. E., and Hake, S. 1993. Overexpression of the maize homeobox gene, KNOTTED-1, causes a switch from determinate to indeterminate cell fates. Genes Dev. 7:787-795.

Soni, R., Carmichael, J. P., Shah, Z. H., and Murray, J. A. H. 1995. A family of cyclin D homologs from plants differentially controlled by growth regulators and containing the conserved retinoblastoma protein interaction motif. Plant Cell 7:85-103.

Sorrell, D. A., Combettes, B., Chaubet-Gigot, N., Gigot, C., and Murray, J. A. H. 1999. Distinct cyclin D genes show mitotic accumulation or constant levels of transcripts in tobacco Bright Yellow-2 cells. Plant Physiol. 119:343-351.

Tréhin, C., Planchais, S., Glab, N., Perennes, C., Tregear, J., and Bergounioux, C. 1998. Cell cycle regulation by plant growth regulators: Involvement of auxin and cytokinin in the reentry of Petunia protoplasts into the cell cycle. Planta 206:215-224.

Vereecke, D., Burssens, S., Simón-Mateo, C., Inzé, D., Van Montagu M., Goethals, K., and Jaziri, M. 2000. The Rhodococcus fascians-plant interaction: Morphological traits and biotechnological applications. Planta 210:241-251.

Yang, W.-C., de Blank, C., Meskiene, I., Hirt, H., Bakker, J., Van Kammen, A., Franssen, H., and Bisseling, T. 1994. Rhizobium Nod factors reactivate the cell cycle during infection and nodule primordium formation, but the cycle is only completed in primordium formation. Plant Cell 6:1415-1426. 